\title{
Proust Configures Time, Space, and Memory to Unveil Marcel's Artistry in Swann's Way
}

\author{
Dr. Tara Hembrough \\ Southeastern Oklahoma State University \\ 425 W University Blvd, Durant, OK 74701, USA
}

\begin{abstract}
As a writer, Marcel Proust questioned approaches to time and memory in artistic composition by abandoning long-accepted conventions of time as chronological in favor of the theory of "duration." With his explorations of temporal and spatial memory, Proust assists in ushering in literature's Modern age. Notably, he exchanges the mentalistic and visualistic path of perception with one sensationalistic in his work. Through Proust's emphasis on the concepts of time, place, and memory in Swann's Way, Marcel, narrating, revisits bygone days, considers family and romantic relationships, discovers that life's patterns repeat themselves, and understands his artistic calling, according to which he can act, bringing closure to the past. While scholars, considering Proust's use of time, have focused on the motif of memory, less has been written about his stylistic choices in portraying his first book's specific measurements of time and space, as well as the types of memories that Marcel holds.
\end{abstract}

Keywords: Proust, Swann's Way, memory, duration, narration, phenomenology, time

1. At the twentieth century's opening, many thinkers became preoccupied with concepts of time and memory. Albert Einstein's theory of relativity prompted scientific, philosophical, religious, and aesthetic discussions of the nature of time, along with new theories for its calculation. In linking the phenomenon of time to memory, Sigmund Freud became the father of modern psychology. As a writer, Marcel Proust questioned approaches to time, space, and memory in artistic composition, abandoning chronological conventions of time in his auto fictional book, Swann's Way (1913), in favor of Henry Bergson's theory of "duration," expressed as a series of distinct and separable moments merged into a single unit of time. With his explorations of temporal and spatial memory, Proust ushers in the Modern literary age, reordering the modal hierarchy of memory access and exchanging the mentalistic and visualistic path of perception with one sensationalistic. "[W] Proust ... was that this type of memory - the recollection of single, unique unrepeatable experiences - was assigned a special function in the quest for the recovery of time and the self" (Meyerhoff, 1955, p. 47).

To compose his magnum opus, Proust took up his pen and reflected upon his childhood and the Belle Époque, a period, like his contemporary one, marked similarly by scientific achievement, artistic movement, and architectural advancement. With France about to engage in World War I, Proust remembered a time to which his country would not return, and in Swann's Way, he delves into the past, combining fiction, autobiography, and philosophy. Edmund Wilson (1930) wrote that Proust chose time as his theme in In Search of Lost Time (19131927), the extended book collection, and through Proust's emphasis on the concepts of time, space, and memory, beginning with Swann's Way, Marcel revisits bygone days, considers family and romance, discovers that life's patterns repeat themselves, and understands his artistic calling, according to which he can bring closure to the past. In doing so, Proust presents his narrative, on the sentence level, linearly, even if he forgoes implementing a progressive plot chronology. While scholars have considered Proust's utilization of time and depiction of memory, from a phenomenological perspective, less has been written about his poetical, stylistic choices in portraying his first book's measurements of time, space, and the types of memories that Marcel possesses. Such adoptions include applying a fluid plot structure; utilizing a lyrical, condensed style built upon a set of complicated images; offering slowly wrought plot climaxes; exploring character interiority; rendering time and space, and object and person, as joined via duration; relying on body memory as opposed to voluntary memory; and defining time as circular to restrict any forward momentum in the plot. 
2. As a first narrative device to organize Swann's Way, as well as the rest of the collection, In Search of Lost Time, Proust applies a fluid plot structure to the work in portraying time as merged with space. Still, in creating a greater order, he references the three quests that Marcel pursues to give shape to the book. In the first journey, Marcel searches for love, analyzes himself, and critiques his society.

In the second, Marcel enters upper-class culture, where he draws conclusions about the morals and manners of the characters he meets. In the third quest, Marcel attempts to identify himself as an artist. However, these three paths cannot serve to structure the bookalone. To emphasize time and memory in Swann's Way, Proust employs a fluid plot structure in order to present time in an expansive, seamless, and uncertain manner as joined with space. "Time and space weave a new fabric - the work of art - comparable to the newly discovered world of quantum physics, but this 'fabric' behaves in an unpredictable manner, as does what is represented within it" (Azerad, 2005, p. 20). With Proust's re-envisioning of time here, readers must search "Marcel's erotic, political, medical, or worldly experiences" to understand how to read the text and "go further afield still and use a principle of selection that is no longer thematic" (de Man, 1979, p. 58) but that is linked with location.

Next, to organize Swann's Way, Proust offers readers a lyrical, sensory-oriented, complicated, and condensed text, so that they must focus on one image at a time in reading, as if scanning a poem. Although Proust composes his work in prose fashion, he renders it, so that one must read the words carefully and pointedly, as if in verse. In order to create a compact text filled with images and actions built tightly upon one another, Proust imposes few paragraph breaks and pens long sentences strung together with clauses and conjunctions to present time as multilayered, containing the past, present, and future in a single configuration. For example, in a single sentence from the madeleine scene, readers learn much about Marcel's food-related rituals, town, relatives, and habits: And once I had recognized the taste of the crumb of madeleine soaked in her decoction of lime-flowers which my aunt used to give me (although I did not yet know and must long postpone the discovery of why this memory made me so happy) immediately the old grey house upon the street, where her room was, rose up like the scenery of a theatre to attach itself to the little pavilion, opening on to the garden, which had been built out behind it for my parents (the isolated panel which until that moment had been all that I could see); and with the house the town, from morning to night and in all weathers, the Square where I was sent before luncheon, the streets along which I used to run errands, the country roads we took when it was fine. (Proust, 1913, p. 51)

To build a series of complicated, interconnected images, Proust utilizes adjectives and adverbs that pack each sentence with sensory detail and render texture to the characters' experiences, as if it is important for him to provide a full discussion of each one's thoughts and events in order to enact a true-to-life, moment-by-moment account. Translator of Proust's work, Lydia Davis states, "Proust's idea of the sentence is that it is one extended thought, with or without ramifications" (Anton, 2004, p. 54). Just as, reflecting back upon the day, one might find that some hours were significant and others not, some of Proust's sentences seem necessary, while others appear to be extraneous, included only because they represent part of the day described. Alfred Whitehead states that a remembered world "'decorated by sense-data" can become "vague, haunting, and unmanageable"” (1959, p.14, 43-44), as there is too much information for readers to register. In some instances, Proust writes with "a proliferation of detail which threatens to undermine the structural assumptions of the genre which contains them" (Johnson, 2014, p. 96), yet his goal is to showcase Marcel's complete and thickly described world.

3. To curb sprawl and maintain reader interest in Swann's Way, as well as the rest of the collection, as another narrative device, Proust creates a pace for the story that extends readers' feelings of intensity for the characters by offering long scenes without space breaks and building the plot episodes over many pages to a climax. Since time is lengthened in the work to include both the important and seemingly mundane, readers get to know the characters and their lives' minute aspects, as if voyeurs watching them through a window for hours on end. In affecting the pacing in his text, the alternate possibility for Proust would have been to write shorter scenes culminating in a series of rapid but perhaps less intense bursts of energy and creating a greater number of conflicts that, when resolved, might have held less import. In some protracted scenes, Proust draws out the action and postpones the climax in order to generate in readers the feelings of suspense, franticness, and even claustrophobia, as if they were watching the action unfold, in reality, minute by minute, instead of on the page. Two such examples of scenes take place when Marcel, as a child, waits for his mother to come upstairs from a party and kiss him goodnight and when Marcel, as a schoolboy, wishes for his crush, the neighbor girl, Gilberte, to declare her love for him in turn. In both scenes, Marcel remains confined to his house during the wait, where the nature's beauty cannot distract him from his thoughts and thus allow time to pass seemingly more quickly. 
In these scenes, the readers feel locked within Marcel's mind, which never stops working, as he analyzes his relationship with Gilberte and anticipates a release with the scene's climax.

4. While as a narrative feature, Proust selects a poetical style for his story and engineers a tight, arduous structure to emphasize time, space, and memory, he also applies the conditional verb tense, stultifies characters' actions, and uses character interiority as techniques to instill the tale's focus on time. Proust uses the conditional verb, "would," to indicate the endless possibilities as to how Marcel, now an old man, could have spent his time in the past or might spend his hours in the future, veering from his current, stultifying habits. The use of the conditional tense allows Proust the possibility of branching out from the novel's trunk, the main plotline, and embarking upon paths that Marcel never actually takes in his real life but that might have been interesting to engage. Having such endless possibilities and remaining obsessed with the past, Marcel commits few actions of consequence in Swann's Way and hesitates to act in the following tomes. Not only are Marcel's actions often internal and mentalistic, but as an old man narrating Swann's Way, he also speaks in the past tense and from a distance, evaluating actions undertaken long ago. Because in Swann's Way, Marcel does not proceed with any sense of real purpose or goal, except to connect with his yesteryears, the narrative lacks forward motion. Effectively, through his meanderings into childhood, Marcel, as an artist, halts any sense of the passing of time. Nevertheless, Walter Pater claims that "we have an interval, and then our place knows us no more . . . for our one chance lies in expanding this interval, in getting as many pulsations as possible into a given time . . for art comes to you proposing frankly to give nothing but the highest quality to your moments as they pass, and simply for those moments' sake" (1868, n.p.). While in Swann's Way, Proust does introduce characters and motifs depicted in In Search of Lost Time, the absence of movement leads to inertia, creating a dream-like effect, which Marcel will capture through art. In this space, he represents "the vanishing point in which the axes of time and space, figure and phenomenon, converge and vibrate, but are never resolved" (Warren, 1995, p. 266), leaving him to contemplations that never cease.

5. As a figure, Marcel represents himself as a precocious child from the upper-middle class, which suffers from little turmoil and enjoys a life of "culture, wealth, and leisure" (Hindus, 1962, p. 25). He depicts his small world, based on village life, as proceeding in a calm, orderly manner, but still, he suffers pain over the years from his interactions. Thus, as an adult looking back, he allows himself time for reflection, and he travels slowly to find safety in his explorations, as he conveys in the madeleine scene: And just as the Japanese amuse themselves by filling a porcelain bowl with water and steeping in it little crumbs of paper which until then are without character or form, but, the moment they become wet, stretch themselves and bend, take on colour and distinctive shape, become flowers or houses or people, permanent and recognizable, so in that moment all the flowers in our garden and in M. Swann's park, and the water-lilies on the Vivonne and the good folk of the village and their little dwellings and the parish church and the whole of Combray and of its surroundings, taking their proper shapes and growing solid, sprang into being, town and gardens alike, from my cup of tea. (Proust, 1913, p. 64)

As a child, Marcel, possessing no other occupation besides school, balances his time, of which he does not yet consider the value as an artist, between the "mundane" and "superficial" and the deep and "profound" (Green, 1949 , p. 6), memories of which spring together from the madeleine's consumption. Growing into adolescence, Marcel engages in writing and walking, and as an adult, he attempts to break into aristocratic society, where he suffers losses in love and friendship. Looking back, Marcel understands that the reality for most males in his world represents their undergoing of a continual series of relational injuries. Therefore, he relies on a levy of positive episodes, beginning with his childhood, to hold back the inevitable, destructive flow of time, which mars the present. In rendering time stylistically, Proust slows the narrative's pace, allowing Marcel to focus on bright episodes and lending the book a ruminative quality: "[I]t was not just a yearning for a simpler, more care-free time, ... Proust's . . . characters feel nostalgic for a time when they were living in a state of grace, feeling connected to their physical environment and . . . believing in the people most who would give them the key values that would sustain them in the years to come, a gold bar against which could be measured all that would give rise to disillusionment" (Fisher, 2011, p. 155).

6. Addressing time and memory through narrative technique, Proust implements duration to join time with space in his work as demonstrated. Bergson argues that an event's time and place "flow together" (Maxwell, 2006, p. 2). Consequently, one can neither calculate time according to a stopwatch, marking each minute discreetly, nor measure time " "homogenous[ly]"” (p. 1). As defining time as chronological depends upon an artificial, ineffective, and outdated scientific and philosophical ideology, Bergson espouses a "natural" and musical view of time 
without stops and starts (p. 1). One must interpret every instant as "indistinguishable" and inseparable from the others, with moments merging through the process of "interpenetration"” (p. 1) and possessing a fluid, dynamic nature. ${ }^{i}$ With duration, one can render time historically, summarily, and elliptically, which Proust does in numerous instances in his text, refusing to portray time as strictly chronological by dividing joined moments into independent segments.

Calculating time as duration, as a narrative device, Proust can collapse time by fusing a series of independent moments or expand it to complicate the narrative, with Marcel sorting out his memories like tokens drawn from a bag. Edward Casey (2000), in Remembering: A Phenomenological Study, explains that when one collapses time, those memories having some similar quality, such as the inclusion of a particular person or place, "knot themselves together" in a "compounding effect," with the time element between the clusters shrinking via a "distending" effect (p. 75). In Swann Way's, an example of this fusion occurs with the drame du coucher scene, in which Marcel, as an old man, has trouble making distinctions amongst the day's hours, places he has visited, and even his numerous identities. Indeed, Proust undergoes "an investigation not only of time, but of the multiple and contingent sel[ves] explored in the unremitting first-person voice of" the narrator (Johnson, 2014, p. 89). Possessing no clear beginning nor end as he awakens in his bed at different hours, Marcel's nocturnal experiences represent what Casey calls the "zone of indetermination" (p. 21), a state in which a memory-frame's edges grow hazy. As Marcel sleeps and awakens, the hours elapsing between day and night grow and shrink. The outside world, inhabited by friends and neighbors, and the inside world of his room, opening onto a window, through which he can observe time's passage, merge. The real and the dream collide in an indeterminable zone in which time's measures seem devoid of place. As a result, "Marcel, the awakening sleeper . . plumbs the abyss of the unknown in search of an informative referent, a datum" (Warren, 1995, p. 261), with Marcel, like Proust, valuing intuition as a knowledge source (Wilson, 1930).

Georges Poulet states that because time does not represent a fixed entity for Proust, who portrays time as duration, as an old man, Marcel fears that the persons, places, and epochs that he has known may disappear into an abyss of nothingness (1987, p. 103), absent even in memory. Indeed, in the drame du coche scene, to facilitate Marcel's sense of time's fusion of events, Proust uses few transitions in joining people, locations, and eras. Here, his "writing mimics affective time, with its flow, its looping back upon itself, its seeming eddies, and sudden jerking forward towards the future" (Locke, 2010, p. 149). Marcel's temporal and spatial confusion at being bombarded with discordant images mirrors readers' own disorientation in trying to untangle the past, present, and future. One's yesterday may inform today and vice versa, a concept Casey (2000) calls "coimmanence," and in the drame $d u$ coche and madeleine episodes, Marcel slips from the present world to the past and back again in a seamless chain of memories, binding his current milieu with forgotten places and those dead and gone. Only because such episodes are slowly paced and contain a fixed setting do readers survive the sense of vertigo, since they cannot prepare for what lies ahead by focusing on the cues that traditional writers might offer in a chronological plot's rising action. In conjunction with Proust's collapsed plot, he expands time and details some episodes to the point of excess, with nothing much occurring. Readers must sacrifice any search for clues to an overall plot, as revealed through how much space any object is given. Instead, they must revel in Proust's poetic images and the widely constructed scenes, such as when Marcel describes the garden. The theory is that, for Marcel, "a coherent selfidentity might be forged in the temporal unfolding of the whole, one that $b$ [inds] together objective social forms of experience with the inner life of the subject" (Johnson, 2014, p. 96).

7. Related to his narrative techniques of fusing separate memories and elongating and contracting historical time, Proust also links past and present events, abandoning absolute linearity in the plot structure as an additional way to present time and memory via duration. Bergson, in defining duration, proposes that time does not necessarily have to follow a linear path, and Proust, in shaping the entirety of In Search of Lost Time, neglects to draw any lines between past and present points in his work. Instead, beginning in Swann's Way, he engineers a series of concentric circles enclosing one another in order to render his plot. With each major episode constituting a separate circle, Proust creates a rippling effect in the overall set of texts. Within this structure, Marcel, as an old man reflecting back, locates himself in a specific place or with a certain person and then moves outward from this center point of gravity, usually into the more distant past, as each scene creates an ever-expanding ring, such as when one throws a stone into a pond. But where does the first circle of memory occur, and how does Marcel generate it, since he feels a sense of disconnection with his past almost like his having an amnesia bout? Nightly, Marcel takes to his bed and reads. 
Before one particular night, he does not recall his youth. Then, Marcel awakens, identifies his family house at Combray and provides iterative, generic memories of his childhood, linked through the process of duration.

While the plot of Swann's Way begins in an open and general manner, then, it grows more specific, and the first circle of memory is fashioned, which will connect to the others through duration. In the drame du coucher episode, Marcel experiences a "habitual" or customary memory associated with his bedtime rituals. Habitual memory is routine, "so that much attending to or heeding [one's] own remembered doing is no longer necessary" (Casey, 2000, p. 56). However, Marcel's customary memory leads next to a "simpliciter" memory, a memory of a single thing apart from other items and episodes (p. 52), as he recalls a specific night when his mother was tardy in coming to kiss him. Here, the narrator becomes an intermediate version of Marcel, the plot narrows, and the second circle is created. Next, the madeleine episode begins, and the narrator's marginalized, secondary memory of Combray appears. While with "primary" memory, one stays "aware of what has just appeared or happened" (p. 49), in "secondary" memory, "experiences that had lapsed from . . consciousness after their initial occurrence" have to be resurrected (p. 50). Now, in Marcel's foray into the past, the plot proceeds along a single line, as the third and greatest circle is created: When Marcel eats the madeleine, a cookie acting in Casey's (2000) terms as an "object simplicitor," one evoking a specific past event, it prompts Marcel's return to childhood, with the narrator remembering his drinking tea with his aunt. Autobiographer of Proust, Richard Barker, believes that the thaumaturgic effects of sensory impression on Marcel serve as a transitional device into retrospection (1958), and Marcel's taste of the madeleine produces a whirlpool sucking him into the past. Here, Proust, like Bergson, identifies an object's ability to stimulate memory as one generated by the person himself or herself, not the object (Fowlie, 1964). In the madeleine episode, Marcel, consuming his cookies, recalls Aunt Leonie, pictures his house and then Combray's buildings and church, and, finally, sees the countryside's scenery beyond. According to Casey, Marcel's retrieval of this memory is "instantaneous," as opposed to "labored," in a process categorized as "remembering that" (2000, p. 51), with the events merged via duration.

As the initial link in moments forged via duration, Marcel's memories, which the madeleine elicits, possess “"singular' objects" as their "specific content" (p. 66-67), namely Combray's architecture and the countryside's geographical features, which constitute the "worldhood" of his memory-frame (p. 68-69), tying it to an identifiable, fixed time. In continuing with Casey's schema defining memory types, Combray's stores and church serve as the memory's "immediate setting," while the scenery beyond represents the memory's "surroundings" (2000, p. 69). Arnold Weinstein, in Recovering Your Story, explains that after consuming the madeleine, Marcel pieces together "an entire village--segment by segment," a landscape of "places and people" (2006, p. 31) spanning multiple books. Proust's collection is structured "symphonically," having a plethora of unstable descriptors with "multiplied associations" (Wilson, 1928, p. 140). In utilizing images, such as the madeleine and tea cup, as symbols, Proust is influenced by the Symbolists (Wilson, 1930, p. 132) but moves beyond them. As a narrator, Marcel must speak his words linearly on the sentence level, as word placement is a grammatical function, but in his text, Proust also offers holistic images, with one wrought from the previous, that are juxtaposed to create meaning instead of his relying on plot chronology.

8. In creating concentric plot circles, as a narrator, Marcel floats through time and space, forgoing the mentalistic cause-and-effect explanations that such nonlinear leaps necessitate through Proust's reliance on duration as a formula for calculating time instead. Normally, for clarity's sake, a nonlinear plot would require explaining a set of events, with any aspects present beforehand and the effects afterward, but Proust forges such connections by implementing body memory to guide readers. While one mentally induces voluntary memory, body memory appears without warning via an uncontrollable and unpredictable flashback, one of value in allowing access to the past. Comparatively, mentally inducing voluntary memory can be arduous, involving an exercising of will power, as Marcel points out in Swann's Way, with one applying intellectual or higher-order mental capacities in order to reengineer an event. Indeed, when Marcel experiences his mother's kiss, he contrasts the two memory types. Voluntary memories may seem lackluster, while involuntary memories are sensationalistic and sensory-based, as Marcel proves in recalling his consumption of the madeleines, which triggered his recollection of family, friends, and neighbors. In the madeleine scene, Marcel relies on body and sensory memory, specifically the use of taste, to lead him backwards in time. James P. Gilroy, discussing food, cooking, and eating in In Search of Lost Time, states that Proust utilizes both concrete and abstract images in portraying Marcel's consumption of the tangible cookie and tea and allowing him to be "perceptive ... to discern[ing] the essence of things beyond their external covering" (1978, p. 98). 
Following the French Romantics, Proust writes introspectively, inclines himself to the natural world, and demonstrates an appreciation for the power of the unconscious and the subjective (Wilson, 1930). Thus, in connecting himself with the metaphysics of Bergson, the Symbolists, and Romantics, Proust denies a wholly scientific view of reality by emphasizing body memory.

As a result of utilizing body memory instead of voluntary memory, Proust cannot order his novel chronologically: In Swann's Way, Marcel pairs "trying to remember" with swimming in the "waters of Lethe" (Proust, 1913, p. 91), where one finds all of human memory lost, as a metaphor illustrating the difficulty of cognitive recollection. According to Casey, body memory, like mentalistic memory, resists narration due to the rigid force of people's habits and customs, but through the process of defamiliarization, or mystifying an otherwise common concept, one can jar memories of prior circumstances (2000). Here, John Hogan, discussing the "past recaptured" and Proust's aesthetic theory, argues that through body memory, Marcel can reach further into the past than possible with "conscious effort" (1939, p. 190). Executing his daily activities one day, Marcel just happens to drink the lime-blossom tea and eat the cake that unleashes his tidal wave of recollections, and Gilroy finds that "[m]emories are preserved in our bodily senses long after" the intellect dispenses with them (1978, p. 101).

Due to Marcel's fixation with reconstituting his past, as issued from a circle of memory created by the madeleine, Proust dedicates more space to the narrator's forgotten history, rendered in flashback, than to the present action, and he hampers the progression of a linear plot, with time as possessing forward movement, as a plot technique. Still, as the narrator, Marcel strains to remember everything of importance to him. According to Casey, a particular memory frame may be "gapp[y]" and contain inexplicable and "unlocalized patches of space," representing an emptiness existing in the full memory (2000, p. 72), and in his writing style, as a narrative device, Proust portrays the effects of a gappiness in memory by omitting definite transitions between words and sentences and by preventing Marcel from recalling everything. For instance, sometimes, Marcel focuses on a central memory set in a specific place and time but will not recollect his journey to or from the location, which might have been automatic in nature. Marcel's travel into what Casey names "remembered space" $(2000$, p. 70$)$ is not a straight arc containing temporal points on a straight line but a series of circles. Some circles, large and welldrawn, encompass the past more completely. Others lose shape when Marcel studies them or become tangents, never reconnecting with the main narrative. Whatever the case, each circle contains a particular break in order to allow readers out of one scene and into the next, born by a new circle. The separate time frames that Proust portrays represent together the moment of remembrance and the moment when the memory was created. "For Proust, the true essence of things, of people, and of places can only be sensed if they can be experienced in two separate time frames simultaneously" (Fisher, 2011, p. 153).

9. In order to create plot order, Proust utilizes duration as a technique in order to forgo a traditional structure and renders association through body memory. Yet, in Swann's Way, he also depicts Combray's people and places by grouping episodes thematically and repeating daily and yearly events of importance to Marcel. By implementing this narrative tactic, Proust juxtaposes the book's scenes instead of having characters leave and enter them in order to create transitions between blocks of action. This repetition of place, character, and season allows readers to familiarize themselves with the book's significant themes and aspects. Additionally, Proust renders the motif of circular time by foregrounding an annual, calendar-like presentation of events: Marcel's family visits Combray for Easter; Saturday becomes special because the family eats early; and Aunt Leonie waits for a friend to visit every Sunday at four. The spring season and a presence of flowers, which Marcel loves, suggest a rebirth continuing the cycle. In contrast, Marcel spends little time discussing winter after equating the snowy Christmas and dark New Year with Gilberte's disappearance, his first love's end, and death's agony.

With Proust's unprecedented plot renovations based upon thematic unity, Swann's Way's lack of chronology and absence of dates create some larger gaps in time that readers cannot reconcile in the text. For instance, readers do not know Marcel's age at any given point, and a missing calendar paired with an unreliable first-person account may make the novel seem less authoritative. Indeed, first-person narrators are perceived as "unreliable" because they cannot accurately and objectively describe themselves in the same manner that a disinterested third person or omniscient narrator might (Booth, 1983). As an old man with little memory of the past and a loose connection to the present, Marcel, like the child narrators and mentally disabled narrators to which he might be compared in other texts (see Booth, 1983), appears doubly suspect in reference to his story's telling. Still, according to Casey's concept of the importance of the "self-presence of the remember," within each memory that might be judged to be a "true" reflection of an account (2000), Marcel himself does appear "at the scene remembered" in every instance 
in which he represents himself as having had the memory (p. 68). Because Marcel serves as an onlooker much of the time in the book, he neglects to remember culturally relevant details that would cement his story as fact and place it within a certain timeframe, and this factor is another that adds to the complexity in following the plot.

Nonetheless, for Proust, the absence of provable facts, which one can link to the narrator, represents part of the story's draw, a tale about generating, validating, and linking memories in order to formulate a continuous whole. Proust "let[s] time take total control of his narrative, to the point where the narrator has slowly dissolved, where the gap between authority, narrative, plot and characters has been abolished" (Azerad, 2005, p. 20). At the end of In Search of Lost Time, readers discover that the complete, multi-volume text does follow an overarching, traditional linear pattern common in nineteenth-century novels, with the author revealing himself in the present tense at the work's beginning before dipping into the past and then reappearing in the conclusion. However, as a pre-Modernist, Proust chooses to group episodes thematically and reinforce the plot structure through a repetition of important images and subjects as a stylistic maneuver.

10. Proust constructs the plot's episodes as blocks of a thematic quilt, sewing together the past and present by linking time, space, and place through duration. For Casey, Aristotle, Kant, and Husserl all share a "monolinear" concept of time in which it "dispers[es]" and "disintegrate[s]" acting phenomena, while memory "collect[s]" or gathers phenomena successively into a singular linear frame $(2000$, p. 181). Aristotle's group views the past as punctiform, yet Casey argues that in memory, one must bind time with place because all recollection involves the body, which locates itself spatially (2000, p. 182). To awaken Marcel's dormant memories, the temporal and spatial modes must work cooperatively. Time singularly becomes free-floating and ethereal, but Proust grounds each textual event in a particular locale, often furnishing elaborate details about where an event occurred or a person abided. Poulet calls this manufacturing of a framework for time and place the process of "localization" (1987, p. 105), and while traditional thinkers, such as Descartes, give precedence to time and its effects alone, Casey contends that place holds the greater import in the consideration. For Casey, one cannot contain time, but one may return to a certain place, and even if this location has changed or its former features have been eradicated, one may still fix the space pictured in one's mind, thus reconstructing it in memory (2000). For instance, if in the drame du cocher episode, Marcel, as an old man, feels flabbergasted, upon awakening, at being unable to ascertain his location, he can utilize his bedroom furniture as a topography with which to familiarize himself with his setting. Later, Marcel will also remember the rooms of his childhood house in Combray before calling forth their former inhabitants.

12. In addition to linking time and place via duration, Proust connects former events with random but evocative objects in order to revive Marcel's dormant memories. The greatest example, as previously discussed, occurs when Marcel pairs his childhood events with the madeleine. Like the cake, seemingly ordinary objects can serve as bridges into a former era. In fact, Marcel believes that in the Celtic religious sacrament in which everyday articles contain the spirits of departed family members and friends, these spirits may only pass into the afterworld when someone notices the objects and hears the messages of those trapped within. As Proust welds time and memory in his narrative, Marcel's bed, books, and the madeleine and tea cup from the aforementioned scenes serve as touchstones for him, providing the impetus to visit the past.

According to Samuel Beckett, discussing "memory," "habit," and "time" in Proust's work, for Marcel, "objects" and "places ... instigate an involuntary memory" (1987, p. 29), one that arrives unexpectedly. Such examples of involuntary memory "are triggered . . . by our sense of smell, taste, sound or touch bumps against something in the present that takes us back to a hidden and unbidden memory in which we experienced this precise sensation in the past" (Fisher, 2011, p. 153). For Proust, involuntary memory holds great importance in Swann's Way, and one will toil without reward if attempting to utilize only mentalistic strategies, instead of objects, in order to access former occurrences and their meanings. While some memories lie on the surface, and one may easily retrieve them, others of significance can elude a person forever until he or she stumbles upon some marker of past. Although in the opening scenes, Marcel nurses no previous nostalgia for cookies and tea, Casey contends that one must identify with specific objects, replicated or actual, such as from childhood, in order to foster an intended "return home" (2000). To free Marcel's clouded memory, Proust marries the past and present by connecting former events with random, evocative objects in the plot.

13. Through Proust's emphasis on time, place, and memory, Marcel understands that life's patterns concerning relationships, friendships, and romances repeat themselves inevitably. In Swann's Way, Proust introduces the motifs of time, loss, and memory, developed in the extended collection's overarching plot structure. As with 
Marcel's ritualistic observances of the day's hours and the year's seasons, Proust emphasizes the circular nature of time in his work through a repetition of generalized plot events in which characters and their counterparts participate. Thematically, each main character possesses a double, if not a triple or quadruple alternate, and thus each character and his/her variants or foils invariably choose a similar path and experience a comparable outcome, even if the former might have learned some lesson from the latter. In the protagonist's case, from a young age, Marcel follows in the footsteps of Swann, a man living in an adjacent property.

Both break into aristocratic and artistic circles, fall in love, experience women's rejection, suffer loss, and question their purposes and careers. Thus, Swann mirrors the narrator himself (Nabokov, 1980). Still, all of the characters display intractable natures, unable to heed the examples of others: They nurse the same obsessions and make the same mistakes, engaging in a series of failed relationships and remaining heartsick. Early on, in In the Shadow of Young Girls in Flower (1919), the collection's second volume, Marcel visits the brothel and finds that love is "hopeless" and creates "unavoidable unhappiness" due to the sexes' incompatibility (Hindus, 1962, p. 69). As a child, Marcel falls in love with his mother; as a youth, with Gilberte; and as a man, with Albertine, and in each instance, he treats the women comparably, obsessing over their affection for him and showing a sense of affectedness or meanness in turn when it supposedly lapses on their part. In Search of Lost Time "is somewhat antiseptic toward romantic illusion, though it is basically a romance" (p. 38), and its continuing plot structure is supported by the repetition of Marcel's and others' relational struggles.

Over the collection's span of four-thousand-odd pages, readers learn about the affairs in which Marcel and his family, friends, and neighbors are involved, and these vary little with the entrance of new participants and the exit of old ones, as history replicates itself throughout the years, even as time passes. Hence, the readers can recreate the text's overarching plot and its greater conflicts by compiling a list of the self-reinforcing tragedies regarding the collection's two-thousand characters. By the end of In Search of Lost Time, Marcel has suffered so much pain and received so much sensory stimulation that readers may wonder how he could have forgotten anything. He has lived a full life, one so full that he must seemingly erase it to make room for new events, and so he does, forgetting everything. By the time Marcel goes to sleep in Swann's Way's, he has thrust thousands of memories into his unconscious and lost touch with them.

14. Nonetheless, through Proust's emphasis on time and memory, as an old man, Marcel reconnects with his artistic calling. In the opening of Swann's Way, Marcel, a lonely, old man without family or associates, sleeps in an empty house, but this pattern will change soon. Marcel hopes to revitalize his past, one he has evoked by consuming a madeleine, and lay the foundation for his new life of becoming a writer. According to Whitehead's definition of "causal efficacy," one perceives that "the settled past" affects the present's construction (Casey, 2000, p. 174). Even so, Marcel, experiencing what Casey calls Marcel's “dawning recognition" (p. 130-131), finds that delving into his yesteryears and exploring the epiphany issuing from a cake does not dispel his current depression. In reflecting upon his boyhood, Marcel moves from the oblivion of remembering nothing to a minute recollection of everything, but what does he gain by such an exchange? Marcel cannot revisit his youth and change those aspects of it that he dislikes; still, he can redeem the past through narrative. Here, he suggests that while time changes people, it does not alter the image that one possesses of them. Thus, in Swann's Way, Marcel, seeking his vocation, journeys from "time lost" to "time regained" (Bree, 1981, p. 26). Because of a vision ignited by a cookie, Marcel discovers his memories of Combray, Balbec, and Paris to be aesthetic and noteworthy. In this case, "Time contains antidotes that art and society need in order to re-establish a harmony which Progress destroys by turning time into an instrument of power and coercion" (Azerad, 2005, p. 20).

With a journey through time and space, Marcel brings closure to the past. As an artist pursuing a solitary life, he will tell his story of growing up. Proust argues that in Finding Time Again (1927), the collection's last volume, "Thanks to art, instead of seeing one world only, our own, we see that world multiply itself and we have at our disposal as many worlds as there are original artists, worlds more different one from the other than those which revolve in infinite space, worlds which, centuries after the extinction of the fire from which their light first emanated, whether it is called Rembrandt or Vermeer, send us still each one its special radiance" (p. 299). Serge Doubrovsky and Carol Bove, describing "the place of the madeleine," writing, and "phantasy" in Proust, state that one's memory is a "creative force . . transforming rudimentary" reminiscence into story $(1975, \mathrm{p} .110)$. Through memory, Marcel will catalogue his life's events, putting them into perspective. Marcel's past moments generate a present transformation within him, and so he will apply an artistic lens to his existence to hold back the oblivion of "eternity" (Hindus, 1962, p. 61). 
In Swann's Way, Marcel struggles against an invisible and ever-changing enemy, time, that distances him from his youth, leaving him a tired man living a deathlike existence. Marcel's "sense of remove" represents what Casey terms an "entfremdungseffekt" (2000, p. 71), and he can only win the battle with time by overcoming a tendency to forget. As a writer, Marcel will save his world from disappearing forever by depicting it for others and acting, according to Proust, as a "repository" of "essential essences" (Proust, 1945, p. 30). Although time's hands separate one from former places, the artist can resurrect old haunts, exorcising them through memory and investigating them through "the blur of years" (Isaacson, 1991, p. 164), by utilizing revolutionary plot structures relying on the merging of time, place, and memory.

\section{References}

Anton, S. (2004). In search of Proust: An interview with Lydia Davis. Brick, 73, 54-59. https://brickmag.com/product/brick-73.

Azerad, H. (2005). The aesthetic/ecstatic time of the Proustian sentence. Journal of Romance Studies, 5(2), 19-36.

Barker, R. (1958). Marcel Proust: A biography. New York, Criterion.

Beckett, S. (1987). Memory, Habit, Time. In H. Bloom (Ed.), Modern critical interpretations: Remembrance of things past (pp. 19-35.) New York: Chelsea.

Bergson, H. (1959). Matter and memory. New York: Doubleday.

Booth, W. (1983). The rhetoric of fiction. Chicago: $\mathrm{U}$ of Chicago P.

Bree, G. (1981). Marcel Proust and deliverance from time. Westport, CT: Greenwood.

Casey, E. (2000). Remembering: A phenomenological study. $2^{\text {nd }}$ ed. Bloomington: Indiana SP.

Doubrovsky, S., \& Bove, C. (1975). The place of the madeleine: writing and phantasy in Proust. Boundary 2, 4(1), 107-134.

Fisher, M. (2011). F. Scott Fitzgerald and Marcel Proust: Literary soul mates. The F. $\quad$ Scott Fitzgerald Review, 9(1), 146160. doi: 10.1111/j.1755-6333.2011.01034.x.

Fowlie, W. (1964). A reading of Proust. London: Dennis Dobson.

Genette, G. (1980). Narrative discourse: An essay in method. New York: Cornell U.

Gilroy, J. (1987). Food, cooking, and eating in Proust's a la recherche du temps perdu. Twentieth Century Literature, 33(1), 98-109.

Green, F.C. (1949). The mind of Proust. Cambridge: Cambridge UP.

Hindus, M. (1962). A reader's guide to Marcel Proust. New York: Farrar.

Hogan, J. (1939). The past recaptured: Marcel Proust's aesthetic theory. Ethics, 49(2), 187-203.

Isaacson, L. (1991). Carl Nielsen's Min fynske barndom: The childhood as literary art.Scandinavica,30(2), 161-204.

Johnson, J. (2014). Rehearing lost time: Proust and Mahler. Romance Studies, 32(2), 88-98. doi:10.1179/0263990414Z.00000000061.

Kristeva, J. (1996). Time and sense: Proust and the experience of literature. (Ross Guberman, Trans.). New York: Columbia UP.

Lewis, C.S. (1958). Allegory of love: A study in medieval tradition. New York: Oxford.

Locke, P. (2010). Intermittences: Merleau-Ponty and Proust on time and grief. Chronotopologies, 146-158.

Macksey, R. (1987). The architecture of time: Dialectics and structure. In H. Bloom Ed.), Modern critical interpretations: Remembrance of things past (pp. 89-97). New York: Chelsea.

Man, P. de. (1979). Allegories of reading: Figurative reading in Rousseau, Nietzsche, Rilke, and Proust. New Haven: Yale UP.

Maxwell, D. (2006). Note on Swann's way.

Meyerhoff, H. (1955). Time in literature. Berkeley: University of California P.

Nabokov, V. (1980). Lectures on literature. New York: Mariner.

Pater, W. (1868). The renaissance studies in art and poetry. www.gutenberg.org/files/2398/2398-h/2398-h.htm.

Poulet, G. (1987). Proustian Space. In H. Bloom (Ed.), Modern critical interpretations: Remembrance of things past (99115). New York: Chelsea.

Proust, M. (1945). "Notebook." La Table Ronde, 2, 30-31. ---. (1927, 1992). In search of lost time. D. Enright (Trans.). New York: Modern Lib.

Warren, J. (1995). The lessons of the living dead: Marcel's journey from Balbec to Douville-Feterne in Proust's cities of the plain: Part two. Studies in $20^{\text {th }}$ Century Literature, 19(2), 258-268.

Weinstein, A. (2006). Recovering your story. New York: Random.

Whitehead, A. (1959). Symbolism: its meaning and effect. New York: Macmillan.

Wilson, E. (1930). Axel's castle. New York: Farrar, Straus and Giroux. ---. (1928). A short view of Proust. New Republic, 54(694), 140-148.

\footnotetext{
${ }^{1}$ See also Gerard Genette's discussion of duration in his work concerning narratology.
} 